\title{
Human leukocyte antigen (HLA) class I frequencies in human T-cell lymphotropic virus type 1 (HTLV-1)-infected patients from Salvador-Brazil
}

\author{
Viviana N Olavarria', Maria F Grassi ${ }^{1}, 2$, Ramon Kruschewsky ${ }^{1}$, Xiao-Jiang Gao ${ }^{3}$, Alline Nascimento ${ }^{1}$, David Watkins ${ }^{4}$,
} Mary Carrigton ${ }^{3}$, Bernardo Galvao-Castro ${ }^{1,2^{*}}$

From 15th International Conference on Human Retroviruses: HTLV and Related Viruses

Leuven and Gembloux, Belgium. 5-8 June 2011

\section{Introduction}

The development of human T- cell lymphotropic virus type 1 (HTLV-1)-associated myelopathy/tropical spastic paraparesis (HAM/TSP) may be related to genetic factors related to the presentation of viral antigens by human leukocyte antigen (HLA).

\section{Aim}

To determine the HLA class I genotype of HTLV-1infected patients.

\section{Methods}

420 HTLV-1-infected patients (280 healthy carriers (HC) and $140 \mathrm{HAM} / \mathrm{TSP}$ ) from the HTLV Reference Center in Salvador, Brazil were evaluated. HLA genotype was performed using automated DNA sequencers and analyzed using the software program Assign-SBT TM 3.2.

\section{Results}

The HLA types most frequently observed in all individuals combined were $A * 02$ (26.1\%), A*03 (10.5\%); B*35 (13.1\%), B*44 (10.4\%), Cw"04 (21.9) and $\mathrm{Cw}^{*} 07$ (17.7\%). The presence of HLA-A 02 reduced the odds of HAMTSP (Odds Ratio: 0.4, p<0.0001 and IC95\%: 0.28-0.59). The frequency of homozygosity of HLA-A was $8 \%, 4 \%$ for HLA-B and 9\% for HLA-C overall. Proviral load was significantly lower in $\mathrm{HC}$ among those heterozygous at all three HLA class I loci group relative to $\mathrm{HC}$ who were homozygous at one or more HLA class I loci group $(\mathrm{p}=0.029)$. However, no difference in homozygosity between proviral load in the HAM/TSP patients was observed $(\mathrm{p}=0.57)$.

\section{Conclusion}

HLA-A*02 allele is more prevalent in the $\mathrm{HC}$ patients, which suggests a protective role of this allele against HAM/TSP. Furthermore, HC patients had a higher frequency of heterozygosity at all three HLA class than that in HAM/TSP patients.

\section{Author details \\ ${ }^{1}$ Bahiana School of Medicine and Public Health (EBMSP) Salvador, Bahia, Brazil. ²Advanced Laboratory of Public Health, Gonçalo Moniz Center, Fundação Oswaldo Cruz, Salvador, Bahia, Brazil. ${ }^{3}$ Laboratory of Genomic Diversity, SAIC-Frederick, Inc., National Cancer Institute, Frederick, Maryland, 21702, USA. ${ }^{4}$ Wisconsin National Primate Center, University of Wisconsin- Madison, Madison, Wisconsin, USA.}

Published: 6 June 2011

\section{doi:10.1186/1742-4690-8-S1-A121}

Cite this article as: Olavarria et al:: Human leukocyte antigen (HLA) class I frequencies in human T-cell lymphotropic virus type 1 (HTLV-1)-infected patients from Salvador-Brazil. Retrovirology 2011 8(Suppl 1):A121.

\footnotetext{
* Correspondence: bgalvao@bahia.fiocruz.br

${ }^{1}$ Bahiana School of Medicine and Public Health (EBMSP) Salvador, Bahia, Brazil

Full list of author information is available at the end of the article
}

(c) 2011 Olavarria et al; licensee BioMed Central Ltd. This is an open access article distributed under the terms of the Creative Commons 